\title{
The Importance of E-assessment in College English Writing*
}

\author{
WANG Ji-jun \\ Inner Mongolia University, Hohhot, China
}

\begin{abstract}
We focused on the e-assessment in college English writing issue from an online assessment tool perspective. Different from previous inquiries, this research addressed the importance of e-assessment in the study of college English writing. In particular, we aim to examine the importance of the e-assessment. We start with a brief introduction of e-assessment. An additional discussion of the use of e-assessment is also provided. We end the study with the conclusion that e-assessment plays an important role in college English writing. We identify in our study that the forms and the effectiveness of assessment in writhing have direct effect on learners' understanding of the curriculum of college English writing and determine their capacity to make advances in college English writing. As a result, we can propose that e-assessment plays a critical role in the learning experience in college English writing.
\end{abstract}

Keywords: e-assessment, online assessment tool, college English writing

\section{Introduction}

Effective educational assessments can foster more effective learning experience for college English learners. Educational assessment is an effective way to analyze what the learners have grasped and what do not. At the same time, educational assessment can determine the needs of learners so as to have them to make progress in the related curricula if appropriate and timely feedback is provided to them. Miller and Parlett (1974) found that the assessment has the greatest and most profound influence to the students. Black and Wiliam (1998b) argued that assessment broadly includes all activities that teachers and students undertake to get information that can be used diagnostically to alter teaching and learning. Brookhart (2001) found that successful students use both marks and feedback and actively self-assess, both to learn and to direct their future studying. Stiggins (2002) also had argued that the "assessment literacy" among teachers, principals, and educators plays an important role.

Generally speaking, educational assessment involves diagnostic assessment, formative assessment, and summative assessment. Diagnostic assessment, also known as initial assessment or pre-assessment, mainly refers to the assessments which are commonly performed before the instruction of any given curricula in order to determine the original level from which the individual's progress can be measured. Formative assessment is usually conducted in the process of the instruction of a course, while summative assessment is generally performed after the instruction of a course is completely finished. The rapid development of information technology has changed the traditional mode of education, and there is no exception to the forms of assessments. The forms of assessments equally face the challenge of information technology in

\footnotetext{
* This paper is under the Planning Projects of Philosophy and Social Sciences of Inner Mongolia (No. 2012C131). WANG Ji-jun, lecturer, master, Foreign Languages College, Inner Mongolia University.
} 
education, so how to use e-assessment to provide feedback to teachers and students over the course of instruction is of key importance.

\section{The Application of E-assessment in College English Writing}

Scalise and Gifford (2006) held that computers and electronic technology today offer myriad ways to enrich educational assessment. The term e-assessment in this paper involves a series of practices in which information technologies are adopted to assess the various aspects of the writing pieces, measuring by computers or by online tools. E-assessment can enhance students' motivation, facilitate their learning, engagement, motivation, and promote students' learning and enhance their writing performance.

\section{The Application of Diagnostic E-assessment}

As demonstrated in Figure 1 (WANG, 2013), diagnostic e-assessment can generalize the detailed information, such as, sentences and paragraphs, mean word length, and mean paragraph length of any individual's writing piece. At the same time, diagnostic e-assessment can obviously display the writing elements, such as spellings, grammar, organization, and logic which direct demonstrate the student writers' writing ability and performance. That is to say, as shown in Figure 1, Teaching Resource Program can determine the original level from which the individual's progress can be measured for it is performed before the instruction of any given curricula.

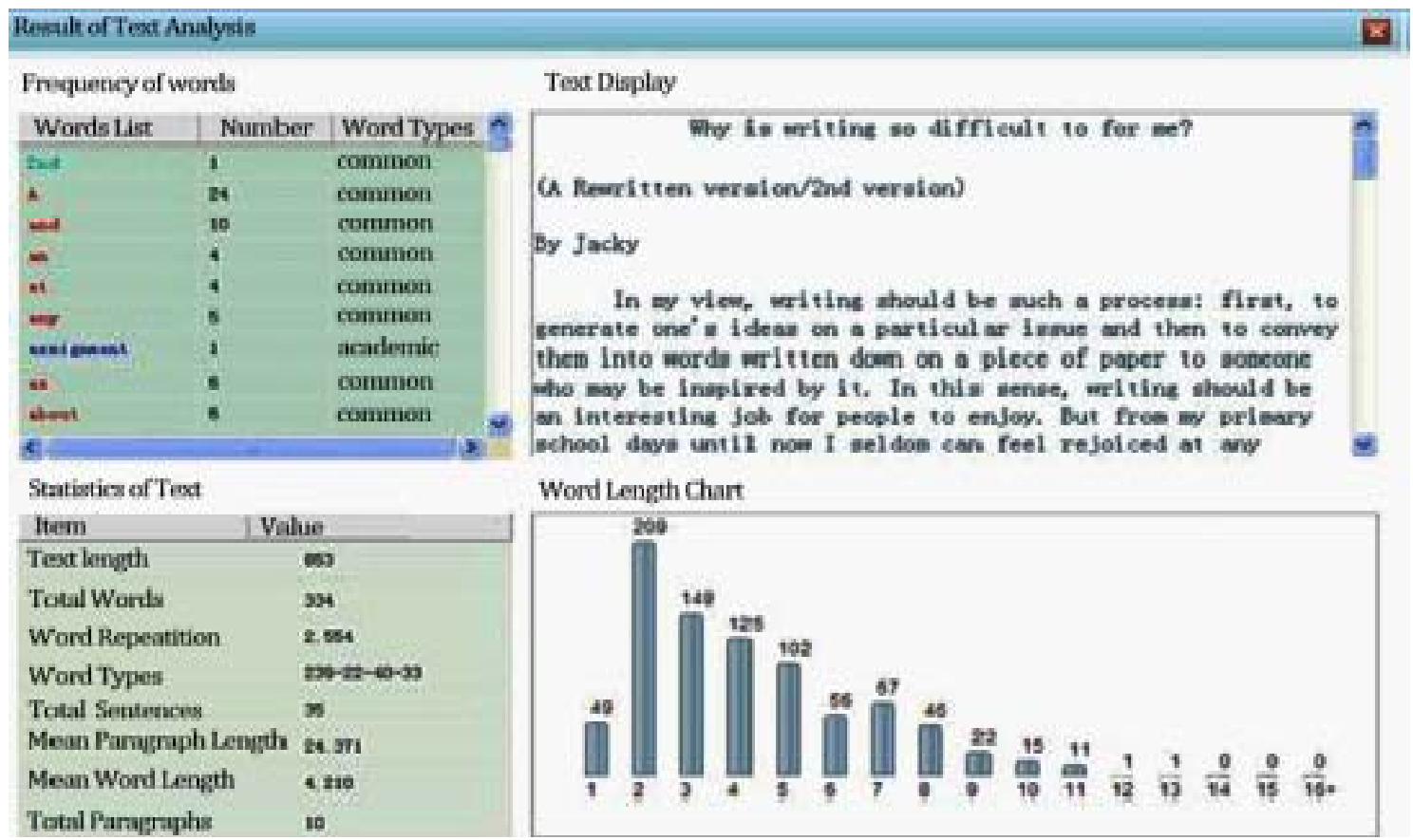

Figure 1. The results of the diagnostic e-assessment by using Teaching Resource Program (an online assessment tool).

\section{The Application of Formative E-assessment}

Formative e-assessment is usually performed in the process of the instruction of a course by computers or by online tools, in order to gain timely and appropriate feedback. Heritage (2011) maintained that the important thing about formative assessment is that it is not a test, nor an instrument, but rather an approach to teaching and learning that uses feedback as its centerpiece in a supportive classroom context and formative assessment is a practice that empowers teachers and students to give their best to enable learning. Formative e-assessment by 
using Teaching Resource Program can provide instant and effective feedback so the students can use e-feedback as instructional action to actively take measures to make advances in their college English writing. Heritage (2011) also argued that feedback is most beneficial when it assists students to understand their current learning status and provides hints, suggestions, or cues for them to act on. Formative e-assessment by using Teaching Resource Program can perfectly acts the function of providing feedback automatically.

\section{The Application of Summative E-assessment}

Summative e-assessment is generally conducted by employing computers or by online tools after a course or project is finished to make a judgment about what the students have learned, typically assigning students the related mark. Garrison and Ehringhaus (2007) held that summative assessments are given periodically to determine at a particular point in time what students know and do not know. Knight (2002) proposed that summative judgments can be formed by simple summation of formative ones. Summative e-assessment by using Teaching Resource Program can instantly mark any given students' pieces, giving out the grade and the rankings which can match human beings in the aspect of validity and reliability.

\section{Conclusions}

E-assessment plays an important part in the learning experience in college English writing. The forms and the effectiveness of assessment in writing have direct effect on learners' understanding of the curriculum of college English writing and determine their capacity to make advances in college English writing. At the same time, the appropriate assessment and timely feedback form a significant part in the whole process of teaching and learning. E-assessment, if properly adopted, will greatly enhance the writing ability of the student writers, and propel the student writers' advances in college English writing.

\section{References}

Black, P., \& Wiliam, D. (1998b). Inside the black box: Raising standards through classroom assessment. Phi Delta Kappan, 80(2), 139-148. Retrieved from http://www.pdkintl.org/kappan/kbla9810.htm

Brookhart, S. M. (2001). Successful students' formative and summative uses of assessment information. Assessment in Education: Principles, Policy and Practice, 8(2), 153-169.

Garrison, C., \& Ehringhaus, M. (2007). Formative and summative assessments in the classroom. Retrieved from http://www.amle.org/Publications/WebExclusive/Assessment/tabid/1120/Default.aspx

Heritage, M. (2011). Formative assessment: An enabler of learning. Better: Evidence-Based Education.

Knight, P. T. (2002). Summative assessment in higher education: Practices in disarray. Studies in Higher Education, 27(3), 275-286.

Miller, C. M. I., \& Parlett, M. (1974). Up to the mark: A study of the examination game. Guildford: Society for Research Into Higher Education.

Scalise, K., \& Gifford, B. (2006). Computer-based assessment in e-learning: A framework for constructing "Intermediate Constraint” questions and tasks for technology platforms. Journal of Technology, Learning, and Assessment, 4(6). Retrieved from http://www.jtla.org

Stiggins, R. J. (2002). Assessment crisis: The absence of assessment for learning. Phi Delta Kappan, 83(10), 758-765.

WANG, J. J. (2013). Effectiveness of teaching resource program in writing evaluation. Academia Journal of Educational Research, 1(3), 40-45. 